\title{
Two red boats in the eye: subhyaloid haemorrhages in anaemic retinopathy secondary to idiopathic aplastic anaemia
}

\author{
Madhushmita Mahapatra, ${ }^{1}$ Subhakar Reddy 다, ${ }^{2}$ Sahil Goel, ${ }^{1}$ Mudit Tyagi ${ }^{2}$
}

'Department of Ophthalmology, Dayanand Medical College and Hospital, Ludhiana, India ${ }^{2}$ Sri Kanuri Santhamma center for Vitreoretinal Diseases, LV Prasad Eye Institute, Hyderabad, India

\section{Correspondence to} Dr Mudit Tyagi; drmudittyagi@gmail.com

Accepted 12 August 2020

\section{Check for updates}

(c) BMJ Publishing Group Limited 2020. No commercial re-use. See rights and permissions. Published by BMJ.

To cite: Mahapatra M, Reddy $\mathrm{S}$, Goel S, et al. BMJ Case Rep 2020;13:e238504. doi:10.1136/bcr-2020238504

\section{DESCRIPTION}

A 11-year-old child presented with gradual diminution of vision in the right eye since 3 weeks. On examination, his best-corrected visual acuity in the right eye was 20/30 N6 and that in the left eye was 20/20 N6. Anterior segment examination was essentially normal in both eyes. Intraocular pressure in the right and left eyes were 16 and $14 \mathrm{~mm} \mathrm{Hg}$, respectively. Fundus examination of the right eye showed dilated and tortuous vessels and two boat-shaped subhyaloid haemorrhages (yellow arrow), one at the inferior macula and the other was inferonasal to the optic disc (figure 1A), and left eye showed optic disc oedema (white arrow) with dilated and tortuous vessels (figure 1B). There was no history of trauma or Valsalva manoeuvre in the recent past, and there was no evidence of any systemic bleeding diathesis. Multipe subhyaloid haemorrhages in a child with the aforementioned fundus picture led us to investigate further for underlying blood dyscrasias. Routine laboratory workup revealed pancytopenia, and bone marrow aspiration showed hypocellularity without any malignant cells. So, a diagnosis of both eyes anaemic retinopathy secondary to idiopathic aplastic anaemia (AA) was made, and the patient was referred to a haematologist. The patient subsequently underwent multiple blood transfusions, along with simultaneous immunosuppression (ciclosporin and danazole).

Multiple subhyaloid haemorrhages or white centred haemorrhages in the retina can be a clue to an underlying blood dyscrasia, and these patients need a detailed haematological evaluation.

$\mathrm{AA}$ is considered as a bone marrow failure syndrome wherein there appears a deficiency of all blood cell types: red blood cells, white blood cells

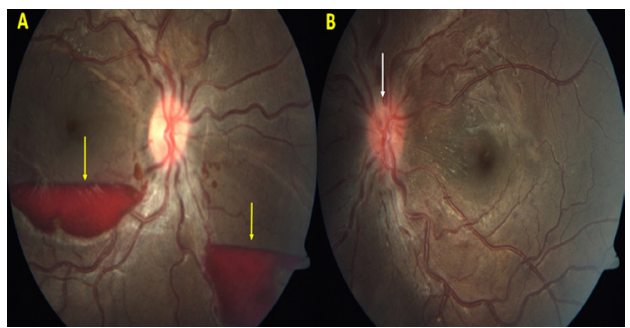

Figure 1 Fundus picture of the right eye $(A)$ showing dilated and tortuous vessels, two boat-shaped subhyaloid haemorrhages (yellow arrow) at the inferior macula and inferonasal to optic disc. Left eye fundus (B) shows optic disc oedema (white arrow) with dilated and tortuous vessels. and platelets. The disease onset itself has a bimodal age distribution. ${ }^{1}$ It may be present at birth or may be acquired due to exposure to radiation, chemotherapy, toxic chemicals, and drug-induced or viral infections. Pancytopenia in AA is due to immunemediated destruction of haematopoietic stem cells, thus leading to bone marrow hypocellularity.

Ocular manifestations of AA are diverese, which include subconjunctival haemorrhages, lid haematomas, rubeosis iridis, retinal haemorrhages, retinal vein occlusions, vitreous haemorrhage, subhyaloid haemorrhages, cotton-wool spots, optic disc oedema, anterior ischaemic optic neuropathy, scleral necrosis and proliferative occlusive vasculopathy. ${ }^{1-3}$ Mansour et al found preretinal haemorrhages as the most common ocular manifestation $(67 \%)$ in patients with AA and optic disc oedema in $6 \%$ of cases as seen in our patient. ${ }^{4}$

Patients with AA can present with systemic bleeding tendencies like gingival bleeding or nasal bleeding; however, in a few cases, it can present with ocular manifestations alone as an initial manifestation. ${ }^{5}$ Our patient had multiple subhyaloid haemorrhages, which prompted us to think of underlying blood dyscrasia. In our patient, an

\section{Patient's perspective}

Father's perspective - My child complained of decreased vision in right eye since 3 weeks and now we came to know that his vision loss is due to underlying blood disorder.I'm thankful to my ophthalmologist in timely diagnosis of this underlying disorder.

\section{Learning points}

All young individuals presenting with retinal haemorrhages, subhyaloid haemorrhages or Roth spots should be evaluated completely for any underlying haematological dyscrasia.

- Anaemic retinopathy secondary to apastic anaemia can present with a vein occlusion- like picture with optic disc oedema and multiple subhyaloid haemorrhages.

- In patients with multiple subhyaloid haemorrhages, ruleout underlying acute severe anaemia or thrombocytopaenia as a cause. 
underlying thrombocytopaenia and AA had led to multiple subhyaloid haemorrhages.

Patients with AA are prone to develop spontaneous severe bleeding, disseminated intravascular coagulation and severe sepsis. Therefore, a timely detection of these retinal changes by an ophthalmologist can be of immense value in such lifethreatening diseases.

Contributors MM and SG were involved in manuscript writing. SR wrote and edited the manuscript and reviewed the literature. MT edited the manuscript and gave the final go.

Funding The authors have not declared a specific grant for this research from any funding agency in the public, commercial or not-for-profit sectors.

Competing interests None declared.
Patient consent for publication Parental/guardian consent obtained.

Provenance and peer review Not commissioned; externally peer reviewed.

\section{ORCID iD}

Subhakar Reddy http://orcid.org/0000-0001-5683-7334

\section{REFERENCES}

1 Mansour AM, Lee JW, Yahng SA, et al. Ocular manifestations of idiopathic aplastic anemia: retrospective study and literature review. Clin Ophthalmol 2014;8:777-87.

2 Shome D, Jain V, Jayadev C, et al. Scleral necrosis in a patient with aplastic anaemia. Eye 2007;21:1017.

3 Agarwal M, Yeh S, Faia LJ, et al. Posterior segment ophthalmic complications of aplastic anemia. Ophthalmic Surg Lasers Imaging 2010;41 Online:e1-6.

4 Mansour AM, Salti HI, Han DP, et al. Ocular findings in aplastic anemia. Ophthalmologica 2000;214:399-402.

5 Wechsler DZ, Tay TS, McKay DL. Life-Threatening haematological disorders presenting with opthalmic manifestations. Clin Exp Ophthalmol 2004;32:547-50.

Copyright 2020 BMJ Publishing Group. All rights reserved. For permission to reuse any of this content visit

https://www.bmj.com/company/products-services/rights-and-licensing/permissions/

BMJ Case Report Fellows may re-use this article for personal use and teaching without any further permission.

Become a Fellow of BMJ Case Reports today and you can:

- Submit as many cases as you like

- Enjoy fast sympathetic peer review and rapid publication of accepted articles

- Access all the published articles

Re-use any of the published material for personal use and teaching without further permission

\section{Customer Service}

If you have any further queries about your subscription, please contact our customer services team on +44 (0) 2071111105 or via email at support@bmj.com.

Visit casereports.bmj.com for more articles like this and to become a Fellow 